\title{
Leucocyte Blood Picture in Healthy Full-term and Premature Babies During Neonatal Period
}

\author{
M. XANTHOU* \\ From the Neonatal Research Unit, Institute of Child Health, University of London, Hammersmith Hospital, London W.1
}

\begin{abstract}
Xanthou, M. (1970). Archives of Disease in Childhood, 45, 242. Leucocyte blood picture in healthy full-term and premature babies during neonatal period. Serial leucocyte counts were done on 15 full-term babies during the first 10 days of life and on 14 prematures during the first 30 days. In addition a single count was done on the total of 53 babies around the 96th hour of life. Absolute values of each cell type are given for each postnatal age examined. The main changes in the leucocyte counts during the neonatal period were found to be as follows: (a) An increase in polymorphonuclear neutrophils after birth, reaching a peak at 12 hours, thereafter dropping to a figure which remains fairly constant from 72 hours onwards. (b) A decrease in polymorphonuclear neutrophil precursors. (c) A drop in lymphocytes reaching a minimum at 3 days of age, and thereafter rising to a steady level at about 10 days. The mean values $\pm 2 S D$ for each cell type at 96 hours of life are as follows. Polymorphonuclear neutrophils: Mean $=4100$ / cu.mm., $M+2 S D=6900 /$ cu.mm., $M-2 S D=1400 /$ cu.mm. Eosinophils: Mean $=700 /$ cu.mm., $M+2 S D=1900 /$ cu.mm., $M-2 S D=200 /$ cu.mm. Lymphocytes: Mean $=3900 /$ cu.mm., $M+2 S D=7100 /$ cu.mm., $M-2 S D=2200 /$ cu.mm. Monocytes: Mean $=1000 /$ cu.mm., $M+2 S D=1800 /$ cu.mm., $M-2 S D=200 /$ cu.mm.
\end{abstract}

Bacterial infections in the newborn still account for a considerable morbidity and mortality. This is partly because the newborn and especially the premature are prone to serious infections by organisms, especially Gram-negative, that are nonpathogenic in older people, and partly because the signs of these infections, both local (inflammatory) and general (fever, etc.) may be absent or minimal and hard to detect. Thus fatal septicaemia may occur with little warning.

The white cell count routinely used in the detection of bacterial infection in children and adults is also thought to be of little value in the newborn.

In reviewing papers written in English, it appears that this subject has not been studied since the late 1930s (Agress and Downey, 1936; Bauza, 1933; Forkner, 1929; Hosen, 1933; Lippman, 1924; Lucas et al., 1921; Rogatz, 1930, 1933; Sanford, 1929; Washburn, 1935; Wollstein, 1938). From 1940 onwards interest seemed to fade; a few

Received 22 September 1969.

^Present address: 9 Maiandrou Str.,"Athens 612, Greece. studies were published (not in English) and these remained more or less unnoticed in the English medical literature (Hinglais and Hinglais, 1949 Klees, Schlagetter, and Wokittel, 1958; Kumar1944; Lee, 1943; Muhl, 1949; Napp, 1950; Nassø and Verga, 1955; Uklonskaya, 1953; Upadhyayes 1945).

The main conclusion drawn by authors of moderi textbooks comes from the studies of the 1930s, an it is that the leucocyte blood picture in the normad newborn is so variable and unpredictable that normal values cannot be established.

For instance, Wintrobe (1967), referring toे Washburn (1935), states, 'during infancy, howevers! the leucocyte count may be very irregular and until the 26th week of life, variations from 5000-24,00 may occur in the absence of demonstrable disease $\frac{\omega}{\sigma}$ Clement Smith (1959) says, 'an exact account (of the white cell count in the newborn) is not only un necessary here but might be more confusing thap valuable, so wide are the ranges of normal variation' This view does an injustice to some of these studies? but nevertheless they were unsatisfactory in severa respects. 
The practice of reporting the differential leucocyte count as a total with percentages of each cell type is scientifically correct since this is, after all, the method by which the leucocyte count is made. However, it is confusing when serial changes are being described, and it is much clearer to express the results in terms of absolute values for each cell type. In some of the older studies only the total counts or the differentials are given. Besides this, only small numbers of babies were studied or only a limited number of counts was made on each baby.

Some of these defects are repaired in the later papers, and Klees et al. (1958) and Straková (1964) provide evidence for a constant pattern of changes in the first few days of life.

However, no investigator has published a systematic study of the dynamics of blood leucocytes in the neonatal period, or studied sufficient numbers to establish biological ranges for each cell type over this period of life.

The purpose of the current study was, therefore, to establish the leucocyte picture of the healthy fullterm and premature baby. The changes seen with illness are the subject of a separate communication.

\section{Material and Methods}

Studies were made on 69 healthy babies, capillary blood being obtained from a free-flowing heel-prick. The 69 babies included the following groups.

Group A (15 full-term babies). The first sample was collected in the first half hour following delivery, thereafter 6-hourly for the first $\mathbf{7 2}$ hours of life and then daily until the 7 th-10th day.

Group B (14 babies, with birthweight less than 2500 g.). 13 were born before the 39 th week, 1 was a small-for-dates baby of 40 weeks' gestation, whose white cell counts did not differ significantly from the others. Again the first sample was obtained within half an hour of delivery, and thereafter samples were collected every 6 hours in the first 24 hours of life and then daily until the 20th-31st day of life; in addition 6-hourly collections were made on a day chosen at random after the 10th day of life in order to look for diurnal variations.

Group C (40 full-term babies). Because the number of healthy babies was too small to show if the counts of each leucocyte cell type were normally distributed, the blood picture of an additional $\mathbf{4 0}$ full-term babies was studied around the 96th hour of life; the time at which the neutrophil count has stabilized.

Total white cell counts were made on a Coulter electronic counter which has an instrumental error of up to $2 \%$. The total error of the method, however, including heel-prick collection, pipetting, and diluting has been estimated as up to $8 \%$.

The films were stained by the combined May-
Grünwald + Giemsa method and cover slips were used.

For the differential examination 2 sets of 100 cells were counted with a repeat examination of a further 200 if the difference between the original counts in respect of any cell-type was greater than $10 \%$.

\section{Results}

There is little to be learnt from the total white cell count in any subiect and especially in the newborn baby; therefore the results reported below are in terms of individual cell types.

\section{(A) Neutrophils}

Polymorphonuclear neutrophils. At birth the polymorphonuclear neutrophils were the predominant cells found in the blood. Each baby showed a marked increase in the absolute value during the first 24 hours of life, reaching a peak at 12 hours.

In full-term babies the mean value was 8000 /cu.mm. at birth, rose rapidly to $13,000 /$ cu.mm. at 12 hours of age, and dropped almost as rapidly to $4000 /$ cu.mm. by 72 hours of age, thereafter remaining stable over the period studied (Fig. 1).

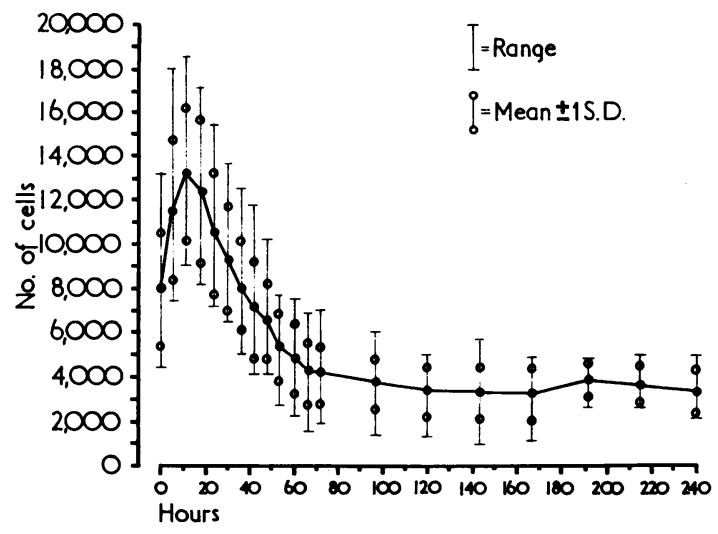

FIG. 1.-Means, ranges, and means $\pm 1 S D$ of neutrophils on 15 full-term healthy babies during the first 10 days of life.

In prematures the mean value at birth was 5000 /cu.mm., at 12 hours $8000 /$ cu.mm., and at 72 hours $4000 /$ cu.mm. Thereafter there was a gradual fall in the mean count, reaching 2500/cu. $\mathrm{mm}$. by the 28th day of life (Fig. 2).

It is worth noting that both in full-term and in premature babies after the first 72 hours of life the absolute values of polymorphonuclears never exceeded 7000/cu.mm. and remained remarkably steady in each baby, so that, in general, daily differences in polymorphonuclear neutrophil counts 
Means and Standard Deviations of Daily Differences in Absolute Values of Polymorphonucied

\begin{tabular}{l|r|r|r|r|r|r|r|r|r|r|r|r|r|r|r|r|r|r|r}
\hline Days & $4-5$ & $5-6$ & $6-7$ & $7-8$ & $8-9$ & $9-10$ & $10-11$ & $11-12$ & $12-13$ & $13-14$ & $14-15$ & $15-16$ & $16-17$ \\
Means & -277 & -111 & -133 & +78 & -142 & -126 & +78 & -28 & -28 & -23 & -83 & -175 & -95 \\
SD & 611 & 476 & 565 & 619 & 342 & 303 & 386 & 309 & 240 & 321 & 236 \\
\hline
\end{tabular}

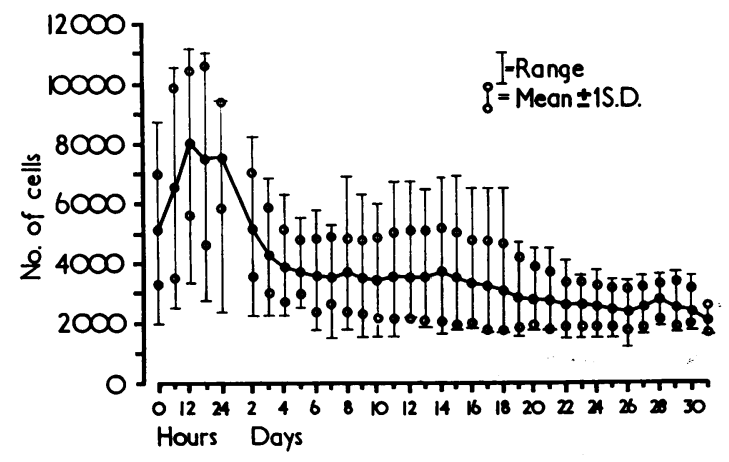

Fig. 2:-Means, ranges, and means \pm 1 SD of neutrophils of 14 healthy babies during the first month of life (13 premature +1 small for dates).

were within the range of experimental error (Table I).

The range of the absolute values of polymorphonuclear neutrophils after the 3rd day of life (Fig. 1 and 2) is due to the differences in values between babies and not to the fluctuations of the value in individual babies.

From Table II it can be seen that there are no obvious changes in neutrophil counts in healthy premature babies from the 10th to the 30th day of life.

TABLE II

Absolute Values of Polymorphonuclear Neutrophils 6-hourly on Random Day after 10th Day of Life

\begin{tabular}{|c|c|c|c|c|c|c|}
\hline \multirow{2}{*}{ Babies } & \multirow{2}{*}{$\begin{array}{c}\text { Age } \\
\text { (dy.) }\end{array}$} & \multicolumn{5}{|c|}{ Hours } \\
\hline & & 12 & 18 & 24 & 6 & 12 \\
\hline $\begin{array}{r}1 \\
2 \\
3 \\
4 \\
5 \\
6 \\
7 \\
8 \\
9 \\
10 \\
11 \\
12 \\
13 \\
14\end{array}$ & $\begin{array}{l}10 \\
10 \\
11 \\
12 \\
12 \\
13 \\
13 \\
15 \\
16 \\
18 \\
20 \\
22 \\
24 \\
26\end{array}$ & $\begin{array}{l}2600 \\
5200 \\
2900 \\
6200 \\
2000 \\
6600 \\
1100 \\
2100 \\
3200 \\
3900 \\
3700 \\
3900 \\
2800 \\
2900\end{array}$ & $\begin{array}{l}3000 \\
5300 \\
3000 \\
6000 \\
2100 \\
6700 \\
1000 \\
2100 \\
3300 \\
3800 \\
3600 \\
4100 \\
3000 \\
2800\end{array}$ & $\begin{array}{l}2800 \\
5200 \\
2900 \\
5800 \\
2200 \\
6600 \\
1100 \\
2200 \\
3100 \\
3600 \\
3700 \\
3900 \\
2900 \\
2800\end{array}$ & $\begin{array}{l}2600 \\
4800 \\
2700 \\
5600 \\
2100 \\
6400 \\
1100 \\
2000 \\
3400 \\
3700 \\
3500 \\
4100 \\
2900 \\
2600\end{array}$ & $\begin{array}{l}2900 \\
4600 \\
2900 \\
5700 \\
2300 \\
6300 \\
1000 \\
2000 \\
3300 \\
3700 \\
3000 \\
4000 \\
2700 \\
2700\end{array}$ \\
\hline
\end{tabular}

The 96-hour values of Group A were added to Group C for analysis of distribution of neutrophil counts at this age.

As seen in Fig. 3, the distribution of neutrophil counts appears to be slightly skewed to the right. However, the $\chi^{2}$ test shows that it is compatible with an arithmetic normal distribution.

The mean of the absolute values at 96 hours of age was $4100 / \mathrm{cu} . \mathrm{mm}$. and the standard deviation $1400 /$ cu.mm.; thus the mean $+2 S D$ is approximately 6900/cu.mm. and -2SD 1300/cu.mm.

Of the observed values all but four fell within the range 2500 to $6500 / \mathrm{cu} . \mathrm{mm}$.; the lowest was $1400 / \mathrm{cu} . \mathrm{mm}$. and the highest was $10,200 / \mathrm{cu} . \mathrm{mm}$. However, this latter count, the only one to exceed $7000 /$ cu.mm., was from a baby who had suffered intrapartum asphyxia and meconium aspiration and who, though well at 96 hours, should not perhaps have been regarded as normal. Since this baby was not excluded in advance, his white cell count has been included in the study.

Band forms. It was found that, in the first 2-3 days of postnatal life, a varying proportion of neutrophils, sometimes half of them, presented as band forms (Fig. 4), but their number decreased thereafter so that by the end of the first week they usually

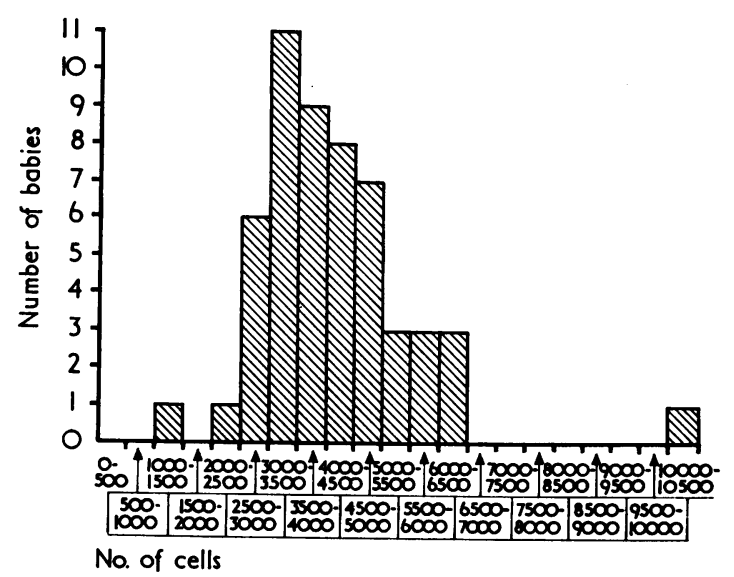

Fig. 3.-Histogram of neutrophils on 53 healthy fullterm babies. 
Ieutrophils on 29 Full-term and Premature Babies from 4th to 30th Day of Life

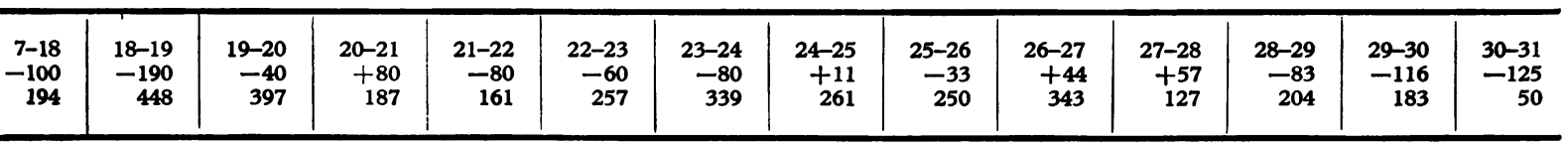

represented a small percentage of the total neutrophil count.

Metamyelocytes. Metamyelocytes in full-term babies were found in greater numbers during the first 3 days of life and practically disappeared by the end of the first week. As shown in Fig. 5, counts of up to $2000 / \mathrm{cu} . \mathrm{mm}$. were found to be normal during the first $\mathbf{7 2}$ hours of life.

Premature babies gave approximately the same picture as full-term babies but with somewhat higher counts during the first 72 hours of life, the upper range approaching $3000 / \mathrm{cu} . \mathrm{mm}$. occasionally. In premature, as well as full-term babies, metamyelocytes had almost entirely disappeared towards the end of the first week of life (Fig. 6). After the first 72 hours of age a metamyelocyte count of over $500 / \mathrm{cu} . \mathrm{mm}$. was very unusual both in premature and full-term babies.

Myelocytes. In healthy full-term babies myelocytes were found within a range from 100 to $750 /$ cu.mm. during the first 3 days of life, while an occasional one was seen up to the end of the first week of life.

Premature babies presented similar findings but with a range of up to $1000 /$ cu.mm. during the first 3 days of life, and in the prematurely born an occasional myelocyte was found up to the 30th day of life.

Promyelocytes. An occasional promyelocyte was sometimes seen in the blood of a healthy newborn baby. This was more frequently noticed during the first days of life and in premature rather than full-term babies.

Blast cells. An occasional blast cell was also encountered in healthy newborns, and as with promyelocytes, more frequently during the first days of life and in premature rather than full-term babies.

(B) Eosinophils. The numbers of eosinophils during the first week of life were variable, ranging

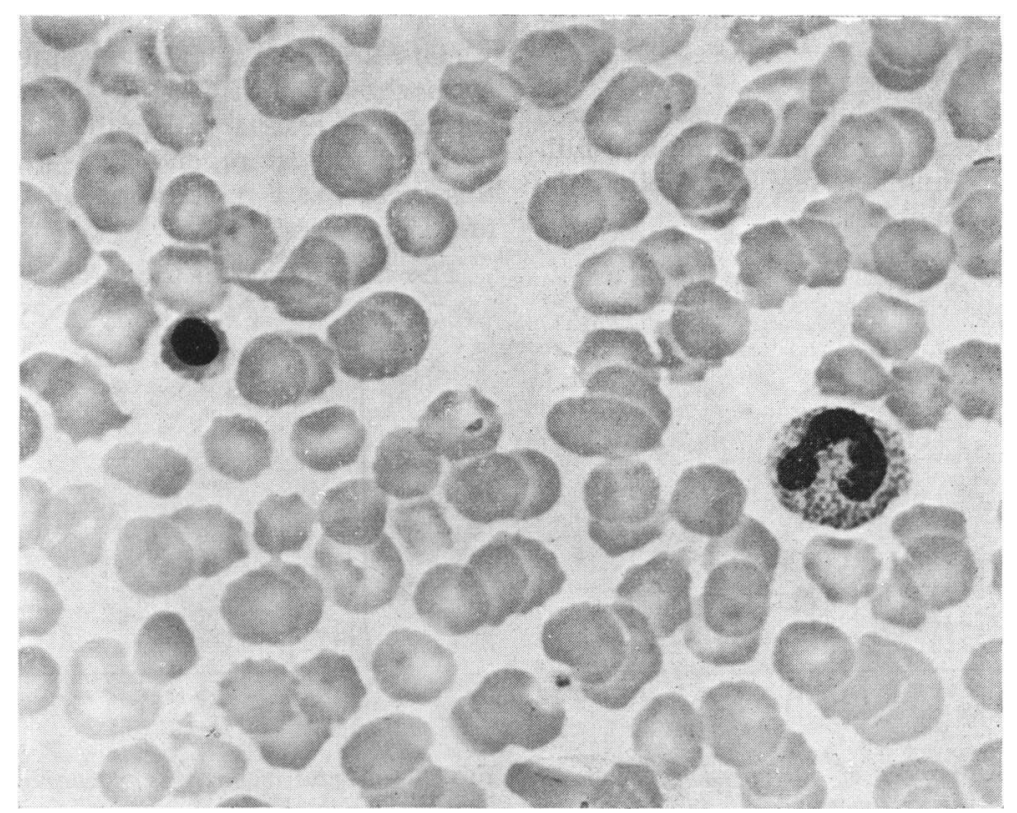

FIG. 4.-A neutrophil band form and a normoblast in the blood of a 24-hour-old baby. 


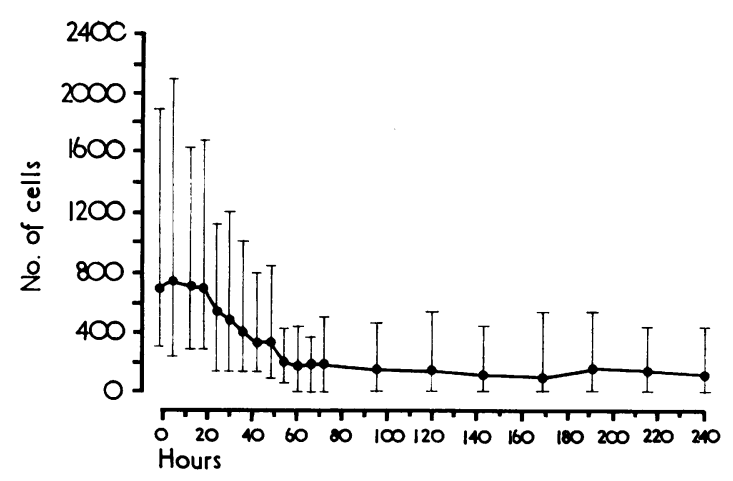

FIG. 5.-Means and ranges of metamyelocytes of 15 fullterm healthy babies during the first 10 days of life.

from 100-2500/cu.mm. both in full-term and premature babies (Fig. 7 and Fig. 8).

The distribution of the eosinophils of 53 healthy full-term babies at the 96th hour of life was logarithmically normal (Fig. 9).

Logarithmic transformation gives the following figures: $M$ ean $=700 /$ cu.mm., $M+2 S D=1900 /$ cu.mm., $M-2 S D=200 /$ cu.mm. The upper figure observed at that time was $1900 / \mathrm{cu} . \mathrm{mm}$. and the lowest $200 /$ cu.mm. In the group of premature babies a steady rise was found after the first week of life, the mean being under $600 /$ cu.mm. during the first week, $800 / \mathrm{cu} . \mathrm{mm}$. at the end of the $2 \mathrm{nd}$ week, and just over $1000 / \mathrm{cu} . \mathrm{mm}$. by the end of the first month (Fig. 8).

(C) Basophils. Basophils were encountered in very small numbers both in premature and fullterm babies. Their numbers tended to follow the rise or fall of the eosinophils.

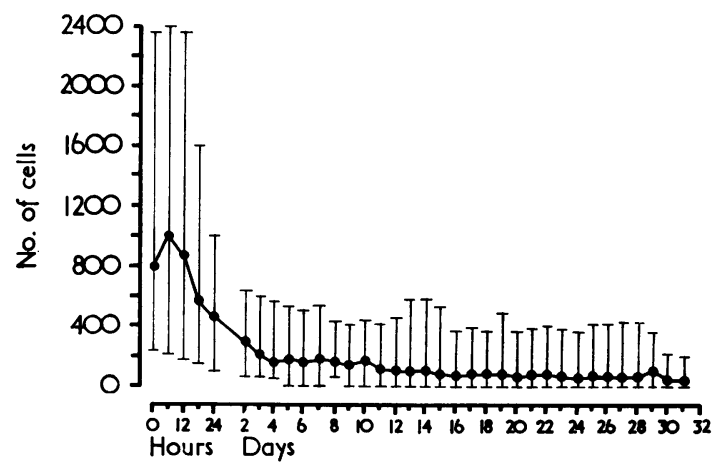

Fig. 6.-Means and ranges of metamyelocytes of 14 healthy babies during the first month of life (13 premature +1 small for dates).

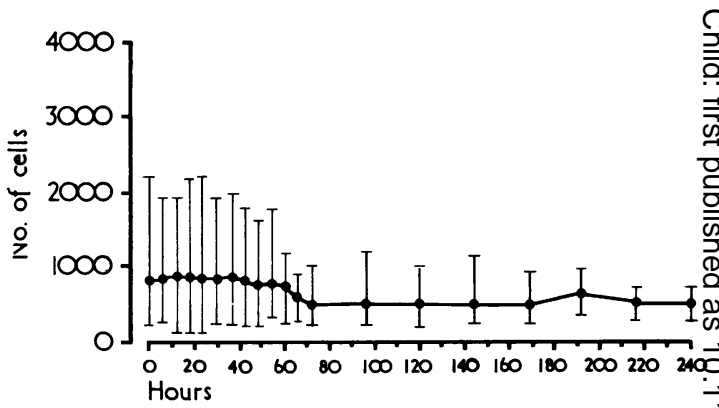

FIG. 7.-Means and ranges of the eosinophils of 15 healthy full-term babies during the first 10 days of life.

(D) Lymphocytes. The absolute values of lymphocytes tended to fall during the first 3 days of life and then rise up to the 10th day both in premature and full-term babies (Fig. 10 and 11).

The distribution of the lymphocytes of 53 healthy full-term babies at the 96th hour of life was logarithmically normal (Fig. 12).

Logarithmic transformation gives the following figures: Mean $=3900 /$ cu.mm. $M+2 S D=7100 \overleftrightarrow{0}$ cu.mm. $M-2 S D=2200 /$ cu.mm. The highesto number observed at that time was $9100 /$ cu.mm and the lowest $2000 /$ cu.mm.

In premature babies the absolute numbers of lymphocytes remained steady after the first 10 days of life.

(E) Monocytes. The absolute values of mono $\frac{\overrightarrow{\vec{\rho}}}{3}$ cytes showed a rise at 12 hours of life, with a subsequent gradual fall until the third day of life both in premature and full-term babies. After this there was a further rise up to the 7th day of응 life (Fig. 13 and 14).

The distribution of the monocytes of 53 healthy?

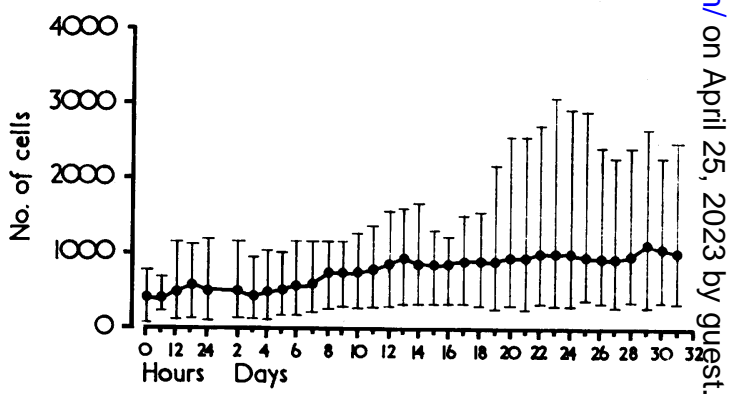

Fig. 8.-Means and ranges of eosinophils of 14 health $3 \frac{0}{5}$ low birthweight babies during the first month of life (130 premature +1 small for dates). 


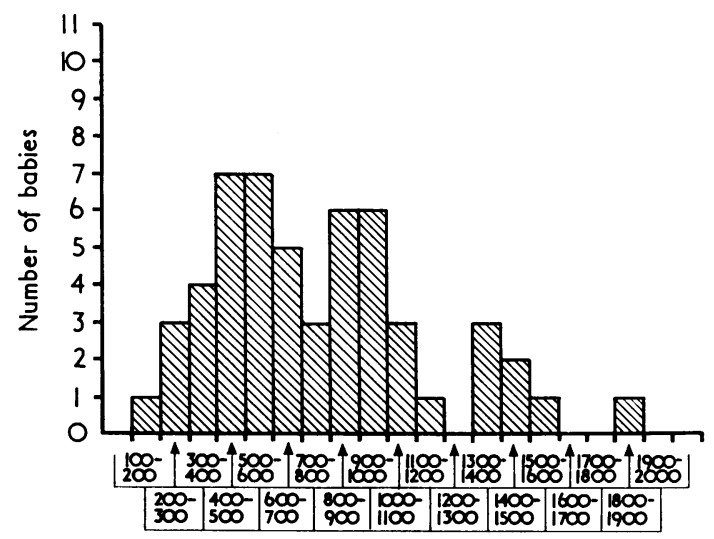

No. of cells

FIG. 9.-Histogram of eosinophils of 53 healthy full-term babies.

full-term babies at the 96th hour of life was normal using arithmetic values (Fig. 15).

The mean value was $1000 /$ cu.mm. and the SD $400 / \mathrm{cu} . \mathrm{mm}$. The observed upper figure at that time was $2100 / \mathrm{cu} . \mathrm{mm}$. and the lowest $300 / \mathrm{cu} . \mathrm{mm}$.

In prematures the mean and ranges were quite steadily maintained after the 10th day of life up to the end of the first month.

\section{Discussion}

There are obvious and significant trends in the peripheral blood of the numbers of the various white cell types in the first few days of postnatal life.

In theory, the number can be increased by: (1) increased production in the marrow; (2) displacement from storage areas, especially the marginal layer of vessels; (3) increased life time in

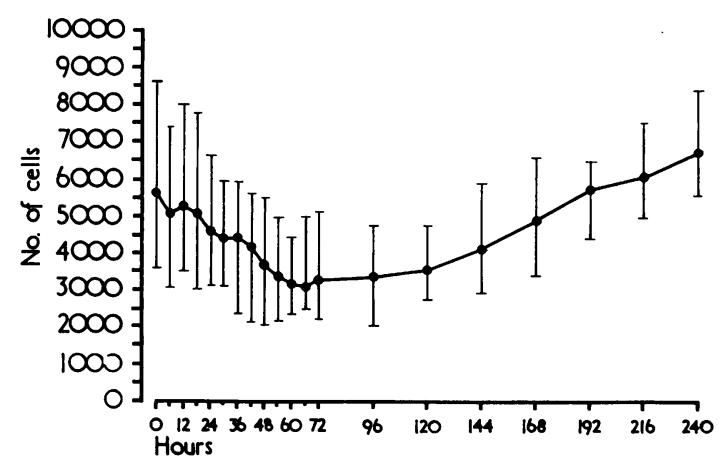

Fig. 10.-Means and ranges of lymphocytes of 15 healthy full-term babies during the first 10 days of life.

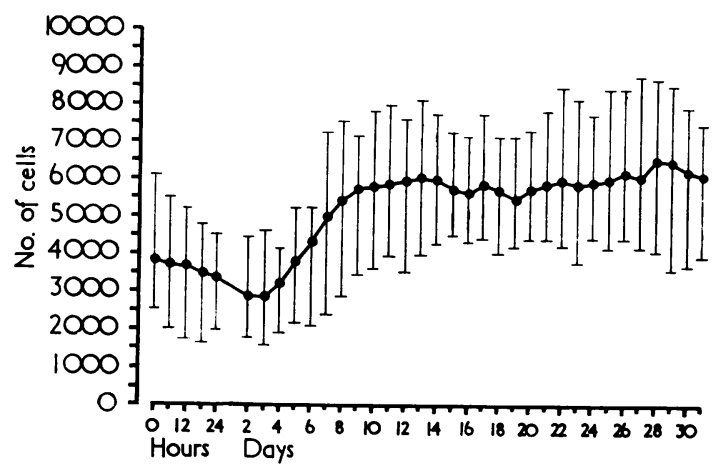

Fig. 11.-Means and ranges of lymphocytes of 14 healthy low birthweight babies during the first month of life (13 premature +1 small for dates).

the blood; (4) decreased passage into tissues; and (5) haemoconcentration.

The reverse of these five situations will decrease the number of white cells in the peripheral blood.

Since the main purpose of this study was to establish normal values, the dynamics of white cell fluctuation will not be discussed in detail. However, certain striking features call for comment.

The most striking change is the enormous rise in neutrophils, which takes place on the first postnatal day (Bayer, 1881; Agress and Downey, 1936; Lippman, 1924; Lucas et al., 1921). This rise fully accounts for the increase in total white cells which has so often been reported.

Since there is a simultaneous decrease in the numbers of lymphocytes and no commensurate

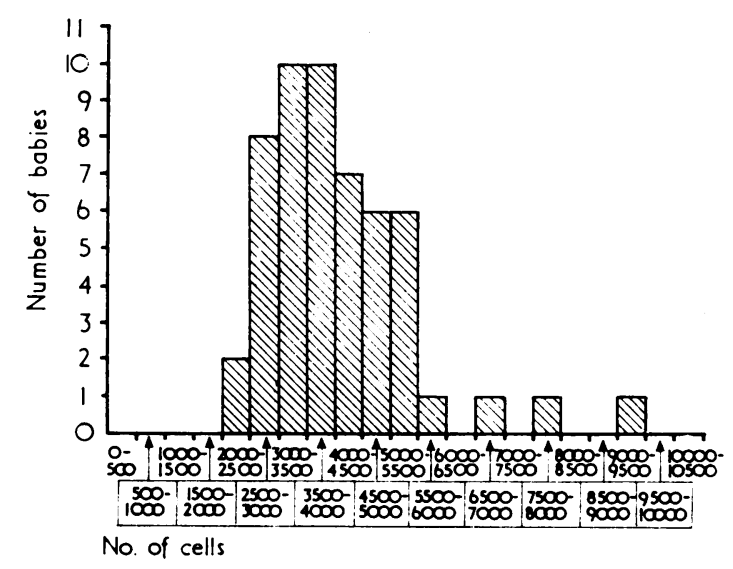

Fig. 12.-Histogram of lymphocytes of 53 healthy fullterm babies. 


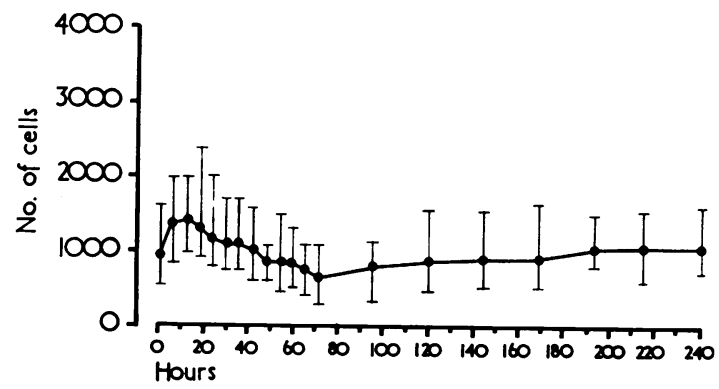

Fig. 13.-The mean and range of the monocytes of 15 healthy full-term babies during the first 10 days of life.

increase in other white cells, it seems most improbable that haemoconcentration, so often invoked to explain this phenomenon (Oski and Naiman, 1966; Schiff, 1892; Wollstein, 1938), is the true explanation.

Since there is only a small rise in neutrophil precursors, it also seems improbable that increased marrow production is the cause of the rise.

The most plausible explanation seems to be the displacement of neutrophils from the marginal layer of vessels. This is known to happen after violent exercise in adults (Boggs, 1967), and in the newborn may well reflect his personal labours in childbirth which is by no means a passive process.

Another striking feature as regards neutrophils is that the absolute values of polymorphonuclears both in full-term and premature babies after the first 72 hours of life never exceeded $7000 /$ cu.mm. or fell below 1000/cu.mm., and remained remarkably steady in each individual baby, so that daily differences in counts were found to be within the range of experimental error. As regards the absence of diurnal changes in polymorphonuclear neutrophil counts in the newborn, this is in keeping with other observations on the absence of diurnal rhythms in the newborn.

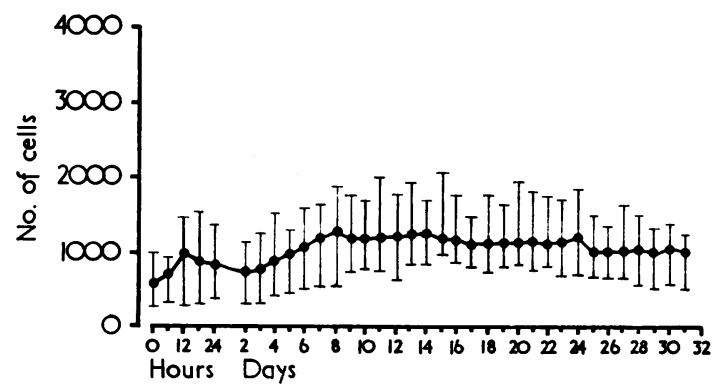

FIG. 14.-Means and ranges of monocytes of 14 healthy low birthweight babies during the first month of life. (13 premature +1 small for dates).

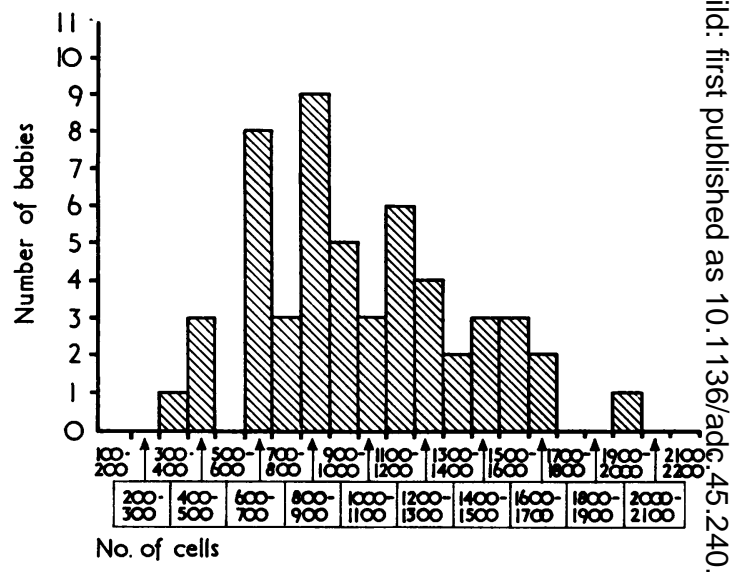

FIG. 15.-Histogram of monocytes of 53 healthy fulli term babies.

The other obvious changes in the neonatal perioct viz. a drop in the numbers of neutrophil precursors:(myelocytes, metamyelocytes) (Agress and Downeyso 1936; Forkner, 1929; Kato, 1935; Lippman, 1924 乌 Sanford, 1929; Washburn, 1935; Wollstein, 1938) the marked drop in lymphocytes in the second an $\$$ third day (Forkner, 1929; Kato, 1935; Lippman? 1924; Wollstein, 1938), and the rise in eosinophils towards the end of the first month (Medoff and Barbero, 1950; Burrell, 1953), are harder to explain As regards the latter trend Medoff and Barberब (1950) have suggested that this could be due to recovery from the hyperadrenal or shock state of birth to the subsequent neonatal hypoadrenalism.

Also noteworthy is the high level of monocytes in the neonatal period, usually exceeding that found in adults (Forkner, 1929; Kato, 1935; Klees et al: 1958; Uklonskaya, 1953).

The most important finding from this study has been the demonstration that quantitative and qualitative changes of white cells in individuap healthy full-term and premature newborn babies follow a remarkably constant pattern during the. neonatal period.

I wish to thank Professor J. P. M. Tizard for suggest ing this study and for his help in the preparation of the paper, and Professor J. V. Dacie, F.R.S., and Dr. D. L. Brown for their advice and instruction. I acknowledge with thanks facilities provided by the Sir William Coxon Trust Fund.

\section{REFERENCES}

Agress, H., and Downey, H. (1936). Blood picture of huma new-borns, with special reference to lymphocytes. Foli Haematologica, 55, 207. 


\section{Leucocyte Blood Picture in Healthy Full-term and Premature Babies}

Bauza, J. A. (1933). Leucocytose et formule leucocytaire chez le nouveau-né. Nourrisson, 21, 29.

Bayer, A. L. (1881). Ueber die Zahlenverhällnisse der roten und weissen Zellen im Blute von Neugeborene und Säuglingen. M.D. Thesis, Berne.

Boggs, D. R. (1967). The kinetics of neutrophilic leukocytes in health and in disease. Seminars in Hematology, 4, 359.

Burrell, J. M. (1953). Comparative study of the circulating eosinophil level in babies. Part II: In full-term infants, 28, 140.

Forkner, C. E. (1929). Studies on the living blood cells of the newborn. Bulletin of the Fohns Hopkins Hospital, 45, 75.

Hinglais, H., and Hinglais, M. (1949). Comment interpréter la formule sanguine de l'enfant; les variations de la formule sanguine de nouveau-né à l'adulte. Semaine des Hópitaux de Paris, 25, 1286.

Hosen, H. (1933). Schilling hemogram in pediatrics. New Orleans Medical and Surgical fournal, 86, 229.

Kato, K. (1935). Leukocytes in infancy and childhood. Fournal of Pediatrics, 7, 7

Klees, E., Schlagetter, K., and Wokittel, E. (1958). Die Bedeutung des Neugeborenenblutbildes in der geburtshilfichen und pădiatrischen Praxis. Zeitschrift für Geburtshilfe und Gynäkologie, 151, 73.

Kumar, B. (1944). Haematological studies in the newborn, with special reference to blood changes during the first week. fournal of the Indian Medical Association, 13, 133.

Lee, P. (1943). Physiology of hematopoietic system in infants and young children, including blood picture at birth and in young infants. Fournal of Pediatrics, 23, 676.

Lippman, H. S. (1924). A morphologic and quantitative study of the blood corpuscles in the new-born period. American Fournal of Diseases of Children, 27, 473.

Lucas, W. P., Dearing, B. F., Hoobler, H. R., Cox, A., Jones, M. R. and Smyth, F. S. (1921). Blood studies in the new-born. American Fournal of Diseases of Children, 22, 525.

Medoff, H. S., and Barbero, G. J. (1950). Total blood eosinophil counts in the newborn period. Pediatrics, 6, 737.
Muhl, G. (1949). On prophylactic and early treatment of infections in newborn infants, especially the premature. Acta Paediatrica, 37, 221.

Napp, G. (1950). Vergleichende Blutuntersuchungen aus Venenund Fersenblut des Neugeborenen. Archiv für Gynäkologie, $178,42$.

Nasso, S., and Verga, A. (1955). Le variazioni numeriche dei globuli bianchi durante le primie ore e i primi giorni di vita. Minerva Pediatrica, 7, 735.

Oski, F. A., and Naiman, J. L. (1966). Hematologic Problems in the Newborn. Major Problems in Clinical Pediatrics, vol. IV. Saunders, Philadelphia.

Rogatz, J. L. (1930). The Schilling blood count in the prognosis of acute infections in infancy and in childhood. American Fournal of Diseases of Children, 40, 70.

- (1933). Schilling blood count in the pneumonias of infancy and of childhood. American fournal of Diseases of Children, 45, 1022.

Sanford, H. N. (1929). The polymorphonuclear count in the newborn. American fournal of Diseases of Children, 38, 271.

Schiff, E. (1892). Neuere Beitrăge zur Hămatologie der Neugeborenen mit besonderer Rücksicht auf die Abnabelungszeit. fahrbuch für Kinderheilkunde und physische Brzichung, 34, 159.

Smith, C. A. (1959). Physiology of the Newborn Infant. 3rd ed. Thomas, Springfield, Illinois.

Straková, M. (1964). White blood picture in newborn infants. (Czech.) Acta Universitatis Carolinae. Medica, 10, 261.

Uklonskaya, R. A. (1953). Leukocyte picture in premature infants during first months of life. (Russian.) Pediatriya, 5, 23.

Upadhyay, S. N. (1945). Blood picture in newborn. Fournal of Obstetrics and Gynaecology, 6, 41.

Washburn, A. H. (1935). Blood cells in healthy young infants. American Fournal of Diseases of Children, 50, 413.

Wintrobe, M. M. (1967). Clinical Hematology. 6th ed. Lea and Febiger, Philadelphia; Kimpton, London.

Wollstein, M. (1938). Normal blood in infants and children. In Handbook of Hematology, Vol. II, p. 923. Ed. by H. Downey. Hoeber, New York; Hamish Hamilton, London.

\section{The following articles will appear in future issues of this journal:}

Treatment of Neuroblastoma with Vitamin B12. By M. J. S. Langman.

Venous Pressure in Congestive Heart Failure in Infancy. By R. H. Burnell.

Effects of Intragastric and Intravenous Sodium Bicarbonate on Rate of Recovery from Post-Asphyxial Acidosis in the Neonate. By R. S. Evans, R. E. Olver, W. J. Appleyard, and C. G. H. Newman.

Cerebro-Costo-Mandibular Syndrome. By B. McNicholl, B. Egan-Mitchell, J. P. Murray, J. F. Doyle, J. D. Kennedy, and L. Crome.

Islet-cell Tumour Causing Hypoglycaemia in a Newborn Infant. By D. B. Grant and P. R. H. Barbor. Suspending Agents in Medicaments As Possible Sources of Galactose to the Galactosaemic Child. By D. E. Bott, P. J. Hopley, and R. H. Leach.

The Effect of Kwashiorkor on the Absorption and Excretion of N, Fat, and Minerals. By R. A. McCance, I. H. E. Rutishauser, and C. N. Boozer.

Effects of Feeding on Respiratory Mechanics of Healthy Newborn Infants. By George Russell and Elizabeth A. Feather.

Renin Levels in Nephroblastoma (Wilms' Tumour) Report of a Renin Secreting Tumour. By J. D. Mitchell, Thelma J. Baxter, J. R. Blair-West, and D. A. McCredie.

Thyroid Function Tests in the Newborn. By M. A. Chadd, O. P. Gray, and D. F. Davies. Cryptococcal Meningitis. By R. McDonald, E. N. Greenberg, and R. Kramer.

Retinal and Conjunctival Haemorrhage in the Newborn. By J. D. Baum and C. J. Bulpitt.

Retinal Vasoconstriction in Premature Infants with Increased Arterial Oxygen Tensions. By J. D. Baum and C. J. Bulpitt.

Cardiovascular Responses to Postural Changes in the Neonate. By C. G. Picton-Warlow.

Effects of Short-term High-Carbohydrate Feeding on Serum Triglyceride of Children with Familial Hypercholesterolaemia. By M. M. Segall, I. Tamir, Audrey S. Fosbrooke, June K. Lloyd, and O. H. Wolff.

Personal Practice Article: Treatment of the Poisoned Child. By D. H. S. Reid.

Valgus Knee Deformities in Children with Juvenile Chronic Polyarthritis treated by Epiphysial Stapling. By B. M. Ansell, G. P. Arden, and I. McLennan. 